DOI: https://doi.org/10.47405/aswj.v6i4.174

\begin{tabular}{|c|}
\hline $\begin{array}{c}\text { Asian Social Work Journal (ASWJ) } \\
\text { ASIANSOCIAL WORK } \\
\text { JORRAL) } \\
\text { (ASW) }\end{array}$ \\
Volume 6, Issue 4, August 2021 \\
\hline \\
\hline
\end{tabular}

\title{
The Paradox of Victims' Perceptions and Knowledge against Flood Causes
}

\author{
Mohamad Shaharudin Samsurijan ${ }^{1}$, Eddy Iskandar ${ }^{1,2}$, Paramjit Singh Jamir Singh ${ }^{1}$, Abdul Rais Abdul \\ Latiff', Muhammad Fikri Ali Yasah ${ }^{1}$ \\ ${ }^{1}$ School of Social Sciences, Universiti Sains Malaysia, 11800 Penang, Malaysia \\ 2Faculty of Social and Political Science, Universitas Mulawarman, Kalimantan, Indonesia
}

Correspondence: Paramjit Singh Jamir Singh (paramjit@usm.my), Abdul Rais Abdul Latiff

(abdulrais@usm.my)

\begin{abstract}
This study aims to unravel the paradox of perceptions and knowledge of the flood victims towards the causes of the disaster in the context of internal and external. Internal context comprises of a comparison of perceptions and knowledge based on individual characteristics (age, gender, education and income). Whereas, the external context includes the factors of the awareness of the victims towards the amount of rainfall, the impact of land use changes as well as the negligence of the responsible parties. The main objective of this study is to determine the differences of perception and knowledge of December 2014 flood victims in Kelantan towards the factors that lead to the flood. This disaster had resulted in huge amount of money lost as well as traumatize the victims in which can be felt to this day. Since that incident, there were various points of view and different perceptions in finding the cause of the disaster occurred. Besides that, the study found that the level of perception and knowledge as to the cause of the disaster is different in the context of the internal (individual characteristics). This difference has a significant influence on the awareness of the causes of the floods that occurred in the external context. Significant relationships at the level of $p<0.05$ has existed between perception and knowledge of the causes of the disaster victims affected by environmental changes in the last 10 years. This indicates that although the victim is aware of the physical environment changes happening around them, but all that is seen is not a major contributing factor to the cause of the floods in Kelantan in 2014.
\end{abstract}

Keywords: flood victims, perceptions, knowledge, flood causes

\section{Introduction}

The floods that hit several states in the east coast of Malaysia at the end of December 2014, especially in Kelantan has invited various reactions. The authority/ responsible bodies are each pointing fingers in blaming each other. Since that issue arises, there were various reactions and speculation arose in finding the cause of a major disaster occurs. The floods that hit Kelantan state were familiar to people in the state. Kelantan and several states in the east coast every year was prone to flood but what sets it apart is the impact of the floods, severe or not, big or small, as well as long or short period of time. This condition actually had given a direct impact on the population, especially in Kelantan when the arrival of the Northeast Monsoon season. Wind monsoons that hit the east coast states occur around October to December each year. 


\section{Asian Social Work Journal (ASWJ), Volume 6, Issue 4, (page 10 - 17), 2021 \\ DOI: https://doi.org/10.47405/aswj.v6i4.174}

However, what is interesting in finding the cause of the flood is the perception and knowledge of the flood victim regards to causes of this disaster happened. According Gandure et al. (2013) and Geoff and Sarah (2016), although the perception of the population has a strong influence on the range of environment, socio economic and socio political but these perceptions are not permanent, but often changeable according to the time period. Perception and knowledge are two-dimensional, which have very different levels of assessment. A good and comprehensive understanding towards the knowledge could make a person perception become valuable and precious. In contrast, the perception of a general nature without leaning with enough knowledge has been put in a situation prone to misinterpretation (Krishanti et al., 2011; Peter et al., 2016; Shavit, 2013). Referring to the floods that had occurred in Kelantan at the end of 2014, the majority of victims see the floods as the most worst that happen in the past 10 years. The incident really gave a long trauma for most of the population as they had loses their homes, jobs, property, livestock and cut off contact with the outside. The experiences of dealing with the situation due to severity of the flood there was no food supply for quite long had given more trauma to the victims. However, this study attempts to determine the extent of dimensional perception of the causes of the flood victims in line with their knowledge of the causes of flooding.

\section{Paradox of perceptions and knowledge of cause flood victims}

Perception and knowledge are two concepts that complement each other. Even age, gender, education, income, religion, interests, place of residence and source of information are often seen as contributing factors in assessing the perception and knowledge in particular (Peter et al., 2016). There are hundreds of studies prove that greatly affects the perception is one individual's knowledge, even one's argumentative perception still is not enough to portray a person knowledgeable about the phenomenon (Roser et al., 2014; Peter et al., 2016). According to Shavit et al. (2013) individual and social perception is also influenced by environmental changes, whether they occur directly or indirectly. Normally, individual and social perception (the victim) would try their best to link the phenomenon to changes occurring in their environment (Roser et al., 2014). All perception is also associated with the sense of identity with the place (topohilia). This situation shows the complexity of the victim's perception is strongly influenced by physical environment, including the social, cultural and cognitive (Peter et al., 2016; Prati et al., 2012). However, the collective dimension of individual perception is seen to represent a dimension of social perception (Roser et al., 2016; Shavit et al., 2013). In other words, both individual and social dimension has led to the cognitive processes that influence the behavior of individuals in particular the effective of involvement in dismantling the causes of the phenomenon (Gandure et al., 2013).

Description and discussion above clearly shows that perception and knowledge are significant in dismantling the cause of a phenomenon. Both the evaluation process, but without the support of evidence, individually perception and knowledge can become doubtful (Jing Liu et al. 2010). In past experiences, matters in concern, information from third parties, the role of media or technology has become too emotional in feelings and strongly influence the perception of the individual (Gandure et al., 2013; Peter, 2016). Perception also contributes to the style of thinking whether one is optimistic, analytical, critical, objective, negative, logical, proactive, passive and etc. These individual thinking qualities will encourage one individual and prove the causes of phenomenon occurs the effect changes in their environment (Jing Liu et al., 2010)

Thus, the victim's experience of the flood disaster has created a unique knowledge for the victim of the expected time when the disaster will occur. However, the scope of the perception of the victims are still in search for the factors that contribute to the occurrence of floods, and yet not to be answered. It is well known that the concept of the knowledge base is a result of what is known by someone. The basic concept of knowledge is strongly influenced by the question of "what". This issue has brought basic input in generating the desire to know by an individual. Knowledge is also seen as a response to one's mental direct experience that gives a logical teaching because something that happens whether it is noticed or unintended. There are several classifications of knowledge often debate by most researchers, especially in the field of environmental psychology are to acknowledge, understand, application, analysis, synthesis and evolution (Donald, 1979; Krishanti et al., 2011; Shavit, 2013). All 


$$
\begin{gathered}
\text { Asian Social Work Journal (ASWJ), Volume 6, Issue 4, (page } 10 \text { - 17), } 2021 \\
\text { DOI: https://doi.org/10.47405/aswj.v6i4.174 }
\end{gathered}
$$

this has contributed to classification adaptation process knowledge to changes in their environment such as consciousness, interested, evolution, trial and adaptation.

\section{Realities, perceptions and knowledge of the flood victims towards the causes of flood}

Reality, perceptions and knowledge are the three aspects that are complementary and have deliberation towards evaluation of the phenomenon. In order to explain the relationship of these three aspects, a study and observation towards the factors that influencing/ contributing towards the causes of the flood argued should be evaluated and considered again.

According to Donald (1979), Jing Liu et al. (2010) and Shavit (2013) perception of people living in a particular place for a long period of time and included the evolution of history, can be considered as a diagnosis of the environmental reality of the past about the location, allowing direct comparison between past and present to be made. Thus, it will make the knowledge of the victims will be empower and the reality on the ground.

\section{Flooding causes and logging and agricultural activities in Kelantan rural areas}

The study conducted by Youngkook (2016), Phong and Rajib (2011) shows that even people living in the same physical environment, but the assessment of the stability of the population or the environment changes greatly influenced by subjective evaluation of different people. They also reflect the relationship of the physical environment and the built environment has a strong significant relationship. This is in line with agricultural projects, logging and plantations implemented by corporate and state government, which has shown how changes in the physical environment occur, the impact of policy development agricultural land for crop Latex Timber Clone (TLC), especially in the northern part of the state. Although, these projects have gone through the process of Environmental Impact Assessment, but in 2014 the state of Kelantan have experienced major flooding. Major flooding is very formidable, even in some other place the incident can be considered such a big flood like the one that occurred in 1967 (PKSK 2015).

Various responses and negative perceptions have pointed fingers at the activity logging, plantations, agriculture and quarrying which were very active over the past 5 years as the source (outside the control of the authorities). In addition, the effects of selected logging and plantation development activities have been manipulated. Propaganda media and other stakeholder groups have seen areas such as Tanah Tinggi Lojing, Gua Musang, Lebir River, Galas River and areas bordering Pahang and Terenganu which cause of the flood. According to the Center for Strategic Studies Kelantan (PKSK) logging activity in the area of Lojing had been frozen since 2006. In fact, the report also pointed out that the system of logging in Kelantan had in fact complied with the annual quota covering 5,960 hectares annually approved by the National Land Council. In fact, forest management has been certified in Kelantan Malaysia Criteria and Indicators for Forest Management Certification Scheme (MTCS). The opening of the project Latex Timber Clone (TLC), all of which have the prior approval of Environmental Impact Assessment. However, given the strong perception that associates relation to logging and agriculture is an undeniably difficult, because according to them the reality on the ground shows the contrary.

\section{The trends approval of the EIA document is rising sharply}

It can be observed trends of the EIA approval document from the year 2000 until 2014 were 222 reports. This number also shows that the increase in projects that have passed the EIA has increased more than 100 percent. The focus of the projects that had received EIA approval is plantations, replantation of agriculture project and logging. All of these projects are related with the opening of the TLC project area especially in the northern state of Kelantan. Therefore, this situation shows that the 


\section{Asian Social Work Journal (ASWJ), Volume 6, Issue 4, (page 10 - 17), 2021 \\ DOI: https://doi.org/10.47405/aswj.v6i4.174}

state government was committed to the development of agricultural projects especially in some areas in rural Kelantan. As a result, it has been given a negative perception when many catchment areas and forest reserves have been explored in order to achieve those objectives. In reality, changes in the physical environment could be seen clearly, and this has given clear feedback that the greed of the project has invited the cause floods in December 2014.

\section{Factors Climate Change: Extraordinary Quantity of Rain}

In addition, there are also opinions that argue that the extraordinary quantity of rain is not the driving cause flood. However, scientific studies that had been made by Strategic Studies Center of the State shows a comparison with the Drainage and Irrigation Department (DID) between 1967 and 2014 in some areas of major rivers (Table 1):

Table 1 Amount of rainfall during the worst flood in 1967 and 2014

\begin{tabular}{llll}
\hline No & Main Rivers & Year 1967 & Year 2014 \\
\hline 1 & Sungai Galas, Dabong & $44.51 \mathrm{~m}$ & $46.47 \mathrm{~m}$ \\
2 & Sungai Kelantan, Tangga Krai & $33.61 \mathrm{~m}$ & $34.17 \mathrm{~m}$ \\
3 & Sungai Kelantan, Jeti Kastam Kota & $6.22 \mathrm{~m}$ & $7.03 \mathrm{~m}$ \\
& Bahru & & \\
\hline
\end{tabular}

The consecutive of three days of heavy rainfall in Gua Musang from 21 to 23 December 2014 that was recorded as high amount of rainfall of $1295 \mathrm{~mm}$ that was equivalent to 64 days. This situation has been known as the phenomenon of December 23, 2014. The record rainfall in the rain at Gua Gagau, Gua Musang on December 23, 2014 is $515 \mathrm{~m}$. This is an unusual phenomenon compared to the same date in Kuala Krai (Dabong $154 \mathrm{~mm}$ and Tualang $164 \mathrm{~mm}$ ). The heavy rain has poured large amount of water into the river of Sungai Pertang and Sungai Badong which it had made an occurrence of strong fast and currents (due to large quantities of water from the top of the mountain) which it was not only hit the plot but also valleys and plains habitation. Then it also hit the Lebir River Valley (abundant throughout the Gua Musang) and the entire valley until the main hit Kelantan River that begins in Kuala Kerai [PKSK 2015].

\section{The Absence Physical Construction}

The events of heavy rainfall and swift river currents has also been linked with the topography and the lack of physical construction can be a buffer. This is because along the river flows of Sungai Lebir and Sungai Galas, there has been no large reservoir area. It can be seen that along these rivers flow (before entering the groove of Sungai Kelantan) it does not have any lake or building of a large water storage reservoirs comparable with Lake Pergau in Jeli. Thus, when the floods hit Kelantan at the end of last December, it involves all regions, except Bachok and Pasir Puteh which the effect was too small/little when the first wave only. Meanwhile, Gua Musang, Kuala Krai and Pasir Mas can be deemed relatively large flood as some parties had classed it as a disaster (as there is a huge amount of damage that had occured) (Mohd Hariri et al., 2015).

\section{Methodology}

This study uses a quantitative approach. A total of 500 participants (flood victims) from 14 villages (32 villages) were directly involved in this study by using questionnaires. The selection of the study area have been through the list of names of villages found in the EIA documents approved in Kelantan during the period 2000 to 2014 (42 selected documents). These villages are located within $5 \mathrm{~km}$ from project site. These villages that have been selected were among the villages that was affected by floods in December 2014. The type village that was involved was a traditional village, organized village, temporary settlements, native village as well as FELDA and FECRA land schemes. Analysis of 


\section{Asian Social Work Journal (ASWJ), Volume 6, Issue 4, (page 10 - 17), 2021 \\ DOI: https://doi.org/10.47405/aswj.v6i4.174}

descriptive and inferential (chi-squared) was used for comparison determining the dimensional of perception and knowledge of the flood victims towards causes of the flood.

\section{Results}

\section{Victims Perceptions vary according to individual characteristics}

The individual characteristics are among the internal factors referring to individual personality, character traits that distinguish one from another (DBP, 2013; Kasimah, 1997). The term characteristic actually comes from the Greek "karasso" which means, " to mark " the mark or engrave that focuses the application of good values in the form of action or behavior (Agni, 2013). Siti Irene (2010) also saw a character of its own nature, its own qualities, moral strength or form of behavior that is found in individual groups.

Robyen (2005), Yuliana and Felix (2012) in discussing the individual functions in the form of characters also reflect the personal characteristics which basically involves gender, skills, knowledge, age and physical condition to see how some individuals convert commodities to function capabilities based on their own abilities, with in other words affect personal character conversion commodity character into the function (the ability of individuals). The characteristics of the environment, how it can enhance or inhibit the function of capacity by environmental conditions such as geographic location, climate, clean air, etc. (Phong \& Rajib, 2011). The results of this study have shown that the perception of victims is different according to the individual characteristics. Income, age, gender, education, income, marital status, descent and occupation of an individual are between the elements that make up the characteristic.

Table 2 Chi squared test between Individual characteristic and cause flooding

\begin{tabular}{llll}
\hline No. & Individual Characteristic & $\mathbf{x}^{\mathbf{2}}$ value & p value \\
\hline 1 & Age & 19.898 & $0.006^{*}$ \\
2 & Gender & 0.343 & 0.558 \\
3 & Education & 26.097 & $0.00^{*}$ \\
4 & Income & 7.164 & 0.067 \\
5 & Marital Status & 3.518 & 0.318 \\
6 & Descent & 80.463 & $0.00^{*}$ \\
7 & Occupation & 10.585 & 0.102 \\
8 & Colony Location & 20.822 & $0.00^{*}$ \\
\hline
\end{tabular}

* significant level $\mathrm{p}<0.05$

Referring to Table 2 clearly shows that the individual's perception of the cause of flooding as a result of agricultural development projects, plantations, logging and mining are the different characteristics of individual followers. Results are seen in parallel with the study by Yuliana and Felix (2012), which argued that the characteristics of individual differences not only lead to the potential difference psychologically, but also build a variety of perception through the changes in their environment. All this will happen as long as the individual is aware of the changes that occur and impact on their daily functions. The study found that age, education level, ethnicity and place of residence have significant relevance to the level of $\mathrm{p}<0.05$. While gender, income, marital status and occupation had no significant relationship at the level of $p<0.05$. These results indicate the victim of various villages have different perceptions of the causes of the floods based on individual characteristics of the victim.

\section{Significant relationships knowledge victims with sensitivity to environmental changes}

The results showed that the majority of victims admitted that agricultural development projects, plantations, logging and mining that occur in their environment strongly influences the physical and 


\section{Asian Social Work Journal (ASWJ), Volume 6, Issue 4, (page 10 - 17), 2021 \\ DOI: https://doi.org/10.47405/aswj.v6i4.174}

environmental changes have a significant relationship at the level of $\mathrm{p}<0.05$. The study also found that the perception of the victim in responding to change in their environment closely related to the knowledge among the population regarding the impact of development projects with changes that had occurred. In line with the argument Tara et al. (2011) and Krisanthi et al. (2010) notice that among the victim has become distinct at the environmental changes surrounding them, thus more effectively establishment of environmental management system into a more sustainable direction. Table 3 shows that there is a significant correlation between the existence of agricultural projects, plantations, logging and mining with the changes in their environment. That is the strength of the relationship that exists around 0.44 until 0.59 . This indicates that the development project also affected the daily life of the changing environment.

Table 3 The relationship strength between the environmental changes and flooding causes

\begin{tabular}{llll}
\hline No. & Changes & $\begin{array}{c}\text { Relation } \\
\text { Strength }\end{array}$ & $\begin{array}{l}\text { p value/ significant } \\
\text { level }\end{array}$ \\
\hline 1 & The daily movement of people & 0.562 & $0.00^{*}$ \\
2 & Housing environment & 0.567 & $0.00^{*}$ \\
3 & Recreation and leisure environment & 0.447 & $0.00^{*}$ \\
4 & Public transportation services & 0.439 & $0.00^{*}$ \\
5 & Infrastructure facility & 0.527 & $0.00^{*}$ \\
6 & Source of income & 0.597 & $0.00^{*}$ \\
7 & Job opportunities & 0.591 & $0.00^{*}$ \\
8 & The number of people who migrate & 0.551 & $0.00^{*}$ \\
9 & Household income & 0.587 & $0.00^{*}$ \\
10 & The level of health of the people & 0.573 & $0.00^{*}$ \\
\hline
\end{tabular}

\section{Victim knowledge about the flood risk is low}

The study also showed that the level of knowledge on disaster risk is very low. Studies conducted Youngkook (2016), Phong and Rajib (2011) shows that there are positive and strong relationships in their environment that reflects the relationship built with the environment. In line with the study results, found that although more than two thirds of victims (Felda Chiku 7; Felda Aring 1 \& 2; Kg. Meranto; Kg Lambok; Kg. Bekok; Kg Perasu) was aware of the existence of projects plantation, agriculture and logging around them will be on a large scale. Only $19 \%$ of the total, respondent's states that the projects that were made were among the contributed cause to the floods occurred in December 2014. The test results show the value of chi-square $\left(x^{2}\right) 36459$ is a high-value $x^{2}$ is significant at the level $\mathrm{p}<0.05(\mathrm{p}=0.00)$. This situation shows most of the victims from various locations in the district of Gua Musang and Kuala Krai were very aware of the existence of land development projects in their environment just as a result of such activities is often seen in noncontributors to the problem of flooding which occurred in December 2014 ago.

\section{The physical environment changing is most felt by the victims}

Majority of the victims saw significant changes in the physical environment that occurs is the river, followed by rolling hills and forest reserves and existing plantations. The most significant change occurred in the past five (5) to ten (10) years. The study conducted by Krisanthi et al. (2010), Phong and Rajib (2011) also proved that exploration of the physical environment without proper planning and sustainable management of the environment has revealed an absolute disaster and destruction. The study also showed that the information from the victim and surveys in the field have found these changes include sediment content in water is very high, shallow depth and width of the narrow river, the hills become bald and barren. In addition, the processes of re-planting on a larger scale makes environmental change are becoming increasingly apparent. Table 4 shows the changes in land use that occurred about 10 years ago until now. 
DOI: https://doi.org/10.47405/aswj.v6i4.174

Graph 1: Physical Environmental Changes

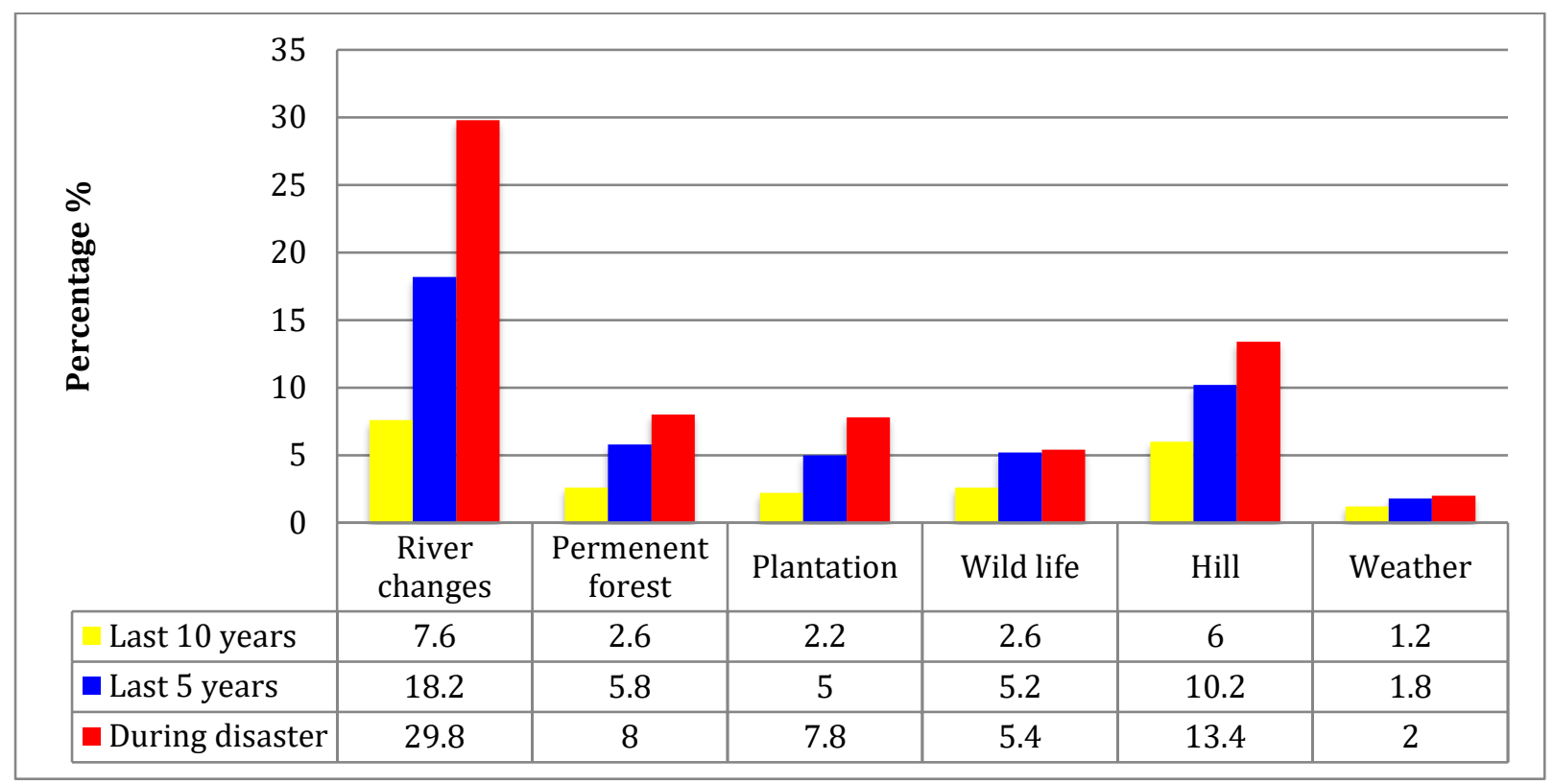

\section{Conclusion}

The dimensional comparison of perception and knowledge that causes the disaster also explains the strength of the victim to adapt to an environment of critical or vulnerable towards disasters. The unbalanced perception and knowledge toward a disaster had put psychological responses among the victim, which tend to blame the stakeholders than the cause of natural events (Krisanthi et al., 2010). This misunderstanding occurs when reality failed to understand the disaster by the victims. The study also proved that the critical factor is when victim's knowledge was obscured towards impact of environmental changes that occur in their environment in the flood disaster. The ability to adapt to the environment is also seen as a critical contributor to the conflict compatibility level of perception and knowledge of the causes of the disaster by the victims.

The significant difference between victims' perception and knowledge of the causes of the flood are influenced by individual characteristics. Characteristic fact about individual psychology has given strength to the flood victims through the subjective evaluation of the changes occurring in the environment. Subjective evaluation is often present in different forms, because it is bound by age, gender, employment status, income, and location of residence, or in other words through a factor in the season.

The level of perception and knowledge of the victim was also influenced by external factors. Victims are vulnerable to disasters also tend to build speculation of sources of information available. However, due to gridlock knowledge to understand the cause of the flood victims scientifically as the amount of rainfall, the impact of land use changes as well as the negligence of the responsible factors have put the victim's psychology tends to use force to formulate a critical and negative thought. However, the study looked at the preparation and explanation consistently or periodically by the stakeholders to be able to unify the gap between perception and knowledge of the victim of a phenomenon (Krisanthi et al., 2010). Which ultimately helps them understand the causes of disasters that proactively and effectively.

\section{Acknowledgements}

This research is conducted by using the research funding of the TRGS/1/2015/USM/01/4/5 project. 


\section{References}

Agni.

(2013).

Definisi

karakter.

$\underline{\text { http://pustaka.padani.web.id/2013/03 }}$ /pengertian- karakter.html. [13 Januari 2016]

Angela Pennisi di Floristella. (2015). Dealing with natural disasters. The Pacific Review, 1-24.

DBP. (2013). Kamus Dewan (Edisi 4). Kuala Lumpur: Dewan Bahasa Dan Pustaka.

Donald Appleyard. (1979). The Environment as a Social Symbol: Within a Theory of Environmental Action and Perception. Journal of the American Planning Association, 45(2), 143-153.

Gandure, S., Walker, S., \& Botha, J.J. (2013). Farmers' perceptions of adaptation to climate change and water stress in a South African rural community. Environmental Development, 5, 39-53.

Geoff A. Wilson \& Sarah L. Dyke. (2016). Pre- and post-installation community perceptions of wind farmprojects: the case of Roskrow Barton (Cornwall, UK). Land Use Policy, 52, 287-296.

Jing Liu, Zhiyun Ouyang \& Hong Miao. (2010). Environmental attitudes of stakeholders and their perceptions regarding protected area-community conflicts: A case study in China. Journal of Environmental Management, 91, 2254-2262.

Kamisa (1997). Kamus Lengkap Bahasa Indonesia. Surabaya: Kartika.

Krisanthi Seneviratne, David Baldry \& Chaminda Pathirage. (2010). Disaster knowledge factors in managing disasters successfully. International Journal of Strategic Property Management, 14 (4), 376-390

Mohd Hariri Arifin, Mohd Nawawi Mohd Nordin \& Azimah Hussin. (2015). Penilaian geofizik dan geologi bagi penentuan lokasi terbaik telaga tiup sebagai sumber air altenatif pasca banjir. (in) Mohd Ekhwan Toriman, Mohd Khairul Ambri Kamarudin, Hafizan Juahir, Muhammad Barzani Gasim, Azizah Endut, Azman Azid \& Roslan Umar (Ed). Bencana Banjir: Kupasan Pelbagai Perspektif, p.p. 125-142. Kuala Terengganu: Penerbit Universiti Sultan Zainal Abidin.

Natalia Pirani Ghilardi-Lopes, Alexander Turra, Marcos S. Buckeridge, Amanda Cristina Silva, Flavio Augusto de Sauza Berchez \& Valeria Marques de Oliveira. (2015). On the perceptions and conceptions of tourists with regard to global environmental changes and their consequences for coastal and marine environments: Acase study of nortrh Sao Paulo State coast, Brazil. Marine Policy, 57, 85-92.

Peter Emmanuel Cookey, Rotchanatch Darnswasdi \& Chatchai Ratanachai. (2016). Local people's perceptions of Lake Basin water governance performance in Thailand. Ocean \& Coastal Management, 120, 11-28.

Phong Tran \& Rajib Shaw. (2011). Towards an integrated approach of disaster and environment management: A case study of Thua Thien Hue province, central Viet Nam. Environmental Hazards, 7(4): 271-282

Pelan Kajian Strategik Kelantan (PKSK). (2015). Flood study in Kelantan. Portal Kerajaan Negeri Kelantan, http://ebanjir.kelantan.gov.my [20 Januari 2016]

Robeyns, I. (2005). The capability approach: a theoretical survey. Journal of Human Development, 6 (1), 93-114.

Roser Rodriguez-Carreras, Xavier Ubeda, Luis Outeiro \& Francesc Aspero. (2014). Perceptions of social and environmental changes in a Mediterranean forest during the last 100 years: The Gavarres Massif Journal of Environmental Management, 138, 75-86.

Siti Irene Astuti. (2010). Pendekatan holistik dan kontekstual dalam mengatasi krisis karakter di indonesia. Cakrawala Pendidikan, XXIX, 41-58.

Tal Shavit, Shosh Shahrabani, Uri Benzion \& Mosi Rosenboim. (2013). The effect of a forest fire disaster on emotions and perception of risk: A field study after the Carmel fire. Journal of Environmental Psychology, 36, 129-135.

Tara O'Connor Shelley, Ted Chiricos \& Marc Gertz. (2011). What about the environment? Assessing the perceived seriousness of environmental crime. International Journal of Comparative and Applied Criminal Justice, 35(4), 307-325.

Youngkook Kim. (2016). Impacts of the perception of physical environments and the actual physical environments on self-rated health. International Journal of Urban Sciences, 1-15.

Yuliana Polishchuk \& Felix Rauschmayer. (2012). Beyond "benefits"? Looking at ecosystem services through the capability approach. Ecological Economics, 81, 103-111. 